\title{
THE RENAL FUNCTION STATUS OF METAL ELECTROPLATING WORKERS EXPOSED TO CHROMIUM VI
}

\author{
Yuliani Setyaningsih ${ }^{1}$, Ida Wahyuni ${ }^{1}$, Ekawati ${ }^{1}$ and Praba Ginandjar ${ }^{2}$ \\ ${ }^{1}$ Occupational Safety and Health Department, Faculty of Public Health, Diponegoro University, Semarang, Indonesia \\ ${ }^{2}$ Epidemiology Department, Faculty of Public Health, Diponegoro University, Semarang, Indonesia
}

Corresponding author: Yuliani Setyaningsih

Email: yulianisupomo71@gmail.com

\begin{abstract}
Chromium ( $\mathrm{Cr}$ ) is commonly used as an anti-corrosive agent. Due to its unique nature, $\mathrm{Cr}$ is used to coat metal in order to make it looks shiny and attractive. However, hexavalent chromium ( $\mathrm{Cr}(\mathrm{VI}))$, a form of chromium used in electroplating, is classified as carcinogenic substance. Its portal of entry into the human body can be through inhalation, ingestion, and dermal absorption. Talang District in central-Java, Indonesia is a center of informal sector's metal electroplating industry. Electroplating workers in the informal sector rarely wear personal protective equipment (PPE) while working. This research analyzed the relation between chromium exposure, age, length of employment, and nutritional status with renal function of metal electroplaters. The subjects of this study involved 35 electroplaters from Talang with working experience ranging between 6 and 40 years. The independent variables were age, length of employment, nutritional status and exposure to chromium. Dependent variable was workers' renal function. Urine samples were collected to determine chromium exposure and renal function based on urinary chromium and creatinine levels. Data was analyzed using chi-square test with SPSS Statistics software. The average urinary chromium and creatinine levels were $21.16 \mu \mathrm{g} / \mathrm{L}$ and $209.75 \mathrm{mg} / \mathrm{dL}$ respectively. This study found no relation between age and chromium levels in urine and renal function. However, length of employment and nutritional status were found to be significantly related to renal function. Although chromium exposure does not appear significantly associate with renal function, the average urinary chromium levels of metal electroplaters did exceed threshold values.
\end{abstract}

Keywords: chromium, electroplating workers, renal function.

\section{INTRODUCTION}

Indonesia's informal sector consists of many workers facing numerous risk of occupational safety and health. One field with known risks is the electroplating services and metal coating process field, in which metal appliances are coated with Chromium $(\mathrm{Cr})$ in order to make them stainless and give them a shiny white appearance.

The chromium used during the metal coating process can also pollute the air in the working environment in a form of mist coming from air bubble in the anode and cathode reactions happened in the coating pool. Hexavalent Chromium $(\mathrm{Cr}(\mathrm{VI}))$, a by-product form of chromium used in electroplating and metal coating is included in chemical material with various chemical characteristics and exposure in the working place. ${ }^{1,2} \mathrm{Cr}(\mathrm{VI})$ is known to be carcinogenic when enters the body particularly through the inhalation resulting not only adverse effect in the respiratory tract but also liver and kidneys organs ${ }^{3-5}$. In the body, $\mathrm{Cr}(\mathrm{VI})$ reduced into $\mathrm{Cr}$ (III) and produces excessive Reactive Oxygen Species (ROS) via Fenton pathway that can lead oxidative stress and DNA structure damage ${ }^{6-8}$.

One of the negative effects is causing renal function disorders ${ }^{9}$. A research of 178 electroplating workers reported renal impairment in nearly $23 \%$ of the subjects 9 . A study in Talang,
Indonesia in 2013 found that in the informal sector, $\mathrm{Cr}$ level in the air and water at electroplating workplaces were above the recommended threshold value $^{10}$. Furthermore, studies of electroplaters in informal sector showed that majority of the workers did not wear any personal protective equipment such as mask, gloves, and work outfit ${ }^{10,11}$.

Creatinine is one of body metabolism by-products. Generally, creatinine filtered by kidneys from the blood and excreted through urine ${ }^{12,13}$. Creatinine levels in blood and urine can be used in the early assessment of renal function disorders ${ }^{14}$. High serum creatinine or urinary creatinine values can be indication of renal function disorders, serum creatinine and urinary creatinine checkup can be used to measure the ability of glomerular filtration rate. Besides showing that chromium exposure in the air and water which were above recommended threshold, Sudarsana also showed a connection between chromium exposures and renal dysfunction among electroplaters in Talang District, Indonesia ${ }^{10}$. This research proposes urine sample collection for determining $\mathrm{Cr}$ and creatinine level; moreover, individual characteristic of electroplaters such as age, working period and nutritional status also will be discussed. 


\section{METHODS}

This research was an observational analytic quantitative study with cross sectional design ${ }^{15}$. The population was all electroplating home industry workers in Talang District as many as 35 electroplaters. Since this research was being done in small electroplating enterprises with few number of electroplaters, total population sampling technique which is a type of purposive sampling method was used in this research with inclusion and exclusion criteria, namely workers had more than one year working experience as electroplaters, never change occupations, did not consume dietary supplement, were not in pregnant condition when data were taken and willing to participate in this study. The workers' urinary chromium, creatinine levels, and certain characteristics were also determined. These characteristics consist of age, length of employment and Body Mass Index (BMI) as assessment of nutritional status. Digital bathroom scale and stature meter are tools for measuring weight and height of the workers in order to calculate BMI by dividing each electroplater's weight in kilograms by their height in meters squared.

Urine samples were drawn on spot 4 hours after electroplaters start working and urine samples were kept a nitric acid treated polypropylene container at $-20^{\circ} \mathrm{C}$ then directly delivered to Balai besar Teknik Kesehatan Lingkungan dan Pengendalian Penyakit (BBTKLPP) laboratory Yogyakarta owned by Ministry of Health Republic of Indonesia to be analyzed. Chromium level in the urine was analyzed using Graphite Furnace Atomic Absorption Spectroscopy (AAS) GF-3000 by BBTKLPP. Graphite furnace AAS was suitable for the study focuses solely on one element and small amount of samples ${ }^{16}$. Urinary creatinine test was used to determine renal function of the workers.
The ethical clearance was requested and was approved by The Health Research Ethics Committee, Public Health Faculty, Diponegoro University filed under 116/EC/FKM2018.

\section{Statistical analysis}

A Chi square test using SPSS Statistics Software was conducted to determine the relation between the workers' age, length of employment, nutritional status, and chromium exposure toward renal function of the workers.

\section{RESULTS}

When the data were taken, almost all of the workers did not use personal protective equipments during their working hours, whether mask, gloves, rubber boots, even the long sleeved clothes. The electroplaters work for approximately 8 hours a day or 40 hours a week. Table 1 shows that more than half of workers were $\geq 40$ years old with average age of 39 years old (SD 6.29). There was greater number of workers who had been working for $\geq 19$ years (51.4\%). Most of the workers $(65.7 \%)$ had normal BMI. Majority of workers $(51.4 \%)$ had chromium level in urine above Biological Exposure Indices (BEI) $10 \mu \mathrm{g} / \mathrm{L}^{17}$ with average $21.38 \mu \mathrm{g} / \mathrm{L}$ and the highest level of chromium in urine was $145.34 \mu \mathrm{g} / \mathrm{L}$. Greater number of workers who had normal level of creatinine in urine $(77.1 \%)$ with average level of creatinine in urine was $210.17 \mathrm{mg} / \mathrm{dL}$.

Table 2 describes age in relation to renal function of metal electroplating workers. We found there was no difference in renal function capacity between workers who were at least 40 years old and those $<40$ years old $(p=0.700)$. The amount of workers with abnormal renal function was equally divided between workers who were at least 40 years old and those younger than 40 years.

Table 1: The Characteristics Distribution of Metal Electroplating Workers in Talang District

\begin{tabular}{|c|c|c|c|c|c|}
\hline Variables & n (\%) & Mean & Median & SD & $\min -\max$ \\
\hline \multicolumn{6}{|l|}{ Age } \\
\hline$\geq 40$ years old & $15(42.9)$ & \multirow{2}{*}{39.69} & \multirow{2}{*}{39.00} & \multirow{2}{*}{6.29} & \multirow{2}{*}{$25-56$} \\
\hline $\begin{array}{l}<40 \text { years old } \\
\text { Length of Employment }\end{array}$ & $20(57.1)$ & & & & \\
\hline$\geq 19$ years & $18(51.4)$ & \multirow{2}{*}{18.86} & \multirow{2}{*}{19.00} & \multirow{2}{*}{7.19} & \multirow{2}{*}{$6-40$} \\
\hline$<19$ years & 17(48.6) & & & & \\
\hline \multicolumn{6}{|l|}{ Nutritional Status(BMI) } \\
\hline Severely Underweight & $1(2.9)$ & \multirow{5}{*}{23.04} & \multirow{5}{*}{23.01} & \multirow{5}{*}{3.82} & \multirow{5}{*}{$15.91-34.23$} \\
\hline Underweight & $2(5.7)$ & & & & \\
\hline Normal & $23(65.7)$ & & & & \\
\hline Overweight & $6(17.1)$ & & & & \\
\hline Obese & $3(8.6)$ & & & & \\
\hline \multicolumn{6}{|c|}{ Chromium level in the urine } \\
\hline$\geq 10 \mu \mathrm{g} / \mathrm{L}$ & $18(51.4)$ & \multirow[t]{2}{*}{21.38} & \multirow[t]{2}{*}{10.13} & \multirow[t]{2}{*}{30.89} & \multirow[t]{2}{*}{$3.50-145.34$} \\
\hline$<10 \mu \mathrm{g} / \mathrm{L}$ & 17(48.6) & & & & \\
\hline \multicolumn{6}{|c|}{ Creatinine Level in the urine } \\
\hline Abnormal & $8(22.9)$ & \multirow[t]{2}{*}{210.17} & \multirow[t]{2}{*}{207.00} & \multirow[t]{2}{*}{105.32} & \multirow[t]{2}{*}{$28.00-479.00$} \\
\hline Normal & $27(77.1)$ & & & & \\
\hline
\end{tabular}


Table 2: Age in Relation to Renal Function of Metal Electroplating Workers in Talang District

\begin{tabular}{|c|c|c|c|c|c|}
\hline \multirow{3}{*}{ Age } & \multicolumn{3}{|c|}{ Renal Function } & \multirow{3}{*}{ Total } & \multirow{3}{*}{$\%$} \\
\hline & Abnormal & \multicolumn{2}{|c|}{ Normal } & & \\
\hline & $\begin{array}{l} \\
\end{array}$ & $f$ & $\%$ & & \\
\hline$\geq 40$ years old & 26.67 & 11 & 73.33 & 15 & 100 \\
\hline$<40$ years old & 20.00 & 16 & 80.00 & 20 & 100 \\
\hline
\end{tabular}

As shown in Table 3 there was found association between working period and renal function capacity $(p=0.041)$. There were $7 \quad(38.89 \%)$ workers in at least 19 years working period group who had abnormal renal function compared to $<19$ years working period group which only had 1
(5.88\%) worker who had abnormal renal function. Moreover there were more workers in $<19$ years working period group who had normal renal function $(94.12 \%)$ compared with workers who had worked for $\geq 19$ years $(61.11 \%)$.

Table 3: Length of Employment in Relation to Renal Function of Metal Electroplating Workers in Talang District

\begin{tabular}{|c|c|c|c|c|c|c|}
\hline \multirow{3}{*}{ Working Period } & \multicolumn{4}{|c|}{ Renal Function } & \multirow{3}{*}{ Total } & \multirow{3}{*}{$\%$} \\
\hline & \multicolumn{2}{|c|}{ Abnormal } & \multicolumn{2}{|c|}{ Normal } & & \\
\hline & $f$ & $\%$ & $f$ & $\%$ & & \\
\hline$\geq 19$ years & 7 & 38.89 & 11 & 61.11 & 18 & 100 \\
\hline$<19$ years & 1 & 5.88 & 16 & 94.12 & 17 & 100 \\
\hline
\end{tabular}

$P=0.041 ; R P=6.611 ; 95 \% \mathrm{Cl}=0.906-48.252$

Relation between nutritional status and renal function capacity of metal electroplating was found with $p=0.038$ (Table 4). There were more overweight workers who had abnormal renal function $(46.15 \%)$ compared to workers with normal (10.53\%) and underweight (0\%) BMI status.
In contrary, all 3 workers with underweight nutritional status (100\%) and majority of workers with normal BMI as many as 17 workers (89.47\%) had normal renal function capacity and 7 workers (53.85\%) with category of overweight had normal renal function.

Table 4: Nutritional Status (BMI) in Relation to Renal Function of Metal Electroplating Workers in Talang District

\begin{tabular}{|c|c|c|c|c|c|c|}
\hline \multirow{3}{*}{ Nutritional Status (BMI) } & \multicolumn{4}{|c|}{ Renal Function } & \multirow{3}{*}{ Total } & \multirow{3}{*}{$\%$} \\
\hline & \multicolumn{2}{|c|}{ Abnormal } & \multicolumn{2}{|c|}{ Normal } & & \\
\hline & f & $\%$ & f & $\%$ & & \\
\hline Underweight & 0 & 0 & 3 & 100 & 3 & 100 \\
\hline Normal & 2 & 10.53 & 17 & 89.47 & 19 & 100 \\
\hline Overweight & 6 & 46.15 & 7 & 53.85 & 13 & 100 \\
\hline
\end{tabular}

Regarding chromium level in urine, it was found no relation between renal function and chromium level in urine $(p=0.909)$. As shown in table 5 there were more workers who had chromium level < $10.13 \mu \mathrm{g} / \mathrm{L}$ with abnormal renal function (35.29\%) compared with workers with $\geq 10.13 \mu \mathrm{g} / \mathrm{L}$ chromium level with abnormal renal function (27.78\%). Furthermore, majority of workers with $\mathrm{Cr}$ level above and under $10.13 \mu \mathrm{g} / \mathrm{L}$ had normal renal function as many as 13 workers $(72.22 \%)$ and 11 workers $(64.71 \%)$ respectively.

Table 5: Urinary Chromium Level in Relation to Renal Function of Metal Electroplating Workers in Talang District

\begin{tabular}{|c|c|c|c|c|c|c|}
\hline \multirow{3}{*}{ Chromium Level } & \multicolumn{4}{|c|}{ Renal Function } & \multirow{3}{*}{ Total } & \multirow{3}{*}{$\%$} \\
\hline & \multicolumn{2}{|c|}{ Abnormal } & \multicolumn{2}{|c|}{ Normal } & & \\
\hline & $f$ & $\%$ & $f$ & $\%$ & & \\
\hline$\geq 10.13 \mu \mathrm{g} / \mathrm{L}$ & 5 & 27.78 & 13 & 72.22 & 18 & 100 \\
\hline$<10.13 \mu \mathrm{g} / \mathrm{L}$ & 6 & 35.29 & 11 & 64.71 & 17 & 100 \\
\hline
\end{tabular}




\section{DISCUSSION}

Previous research confirmed that the industrial electroplating workers were exposed to $\mathrm{Cr}$ $(\mathrm{VI})^{10,18}$. The average amount of urinary chromium exceeding the threshold limit value was lower than the average found in a study by Sudarsana ${ }^{10}$. Related to this study, workers were found working without any PPE while a study of workers exposure to chromium by Decharat stated that using PPE can reduce exposure of chromium to workers ${ }^{19}$.

This study showed no significant link between age and renal function. However, as table 2 demonstrates, workers younger than 19 more often had normal renal function than older workers. However, a similar study did find a negative correlation between age and urinary creatinine $^{20}$. As workers age, there will be alterations in physiological renal function, such as Glomerular Filtration Rate (GFR) decreasing. This alteration can make older workers more vulnerable to stimuli that may have adverse effects on their kidneys as compared to younger workers ${ }^{21}$. From around the age of 40 , the kidneys start losing nephrons, contributing to a renal function decrease roughly $10 \mathrm{ml} /$ minute $/ 1.73 \mathrm{~m}^{2}$ every 10 years. Thus, when reaching 40 years old, minor damage resulting in a GFR value of $60-89$ $\mathrm{ml} /$ minute $/ 1.73 \mathrm{~m}^{2}$ is expected. In other words, renal function declines $10 \%$ resulting in a reduced ability of the kidneys to filter creatinine via the glomerulus ${ }^{22}$.

We found a significant relation between electroplating workers' length of employment and renal function (table 3 ). The longer electroplaters work in an environment where they are exposed to chromium, the higher the exposure accumulation risk they got. Likewise, previous studies showed that as urinary $\mathrm{Cr}$ increases, 8Hydroxydeoxyguanosine (8-OHdG) and malondialdehyde (MDA) increase with it ${ }^{3,23,24}$. These are biomarkers of oxidative stress derived damage to DNA. Within the glomerulus are mesangial cells in the epithelial tissue that function as the immune response if a toxic substance enters the kidney. These mesangial cells are equipped with $\lg \mathrm{C}$ and $\mathrm{C} 3$ immune systems that specifically counter toxic substances. An extended length of employment causes frequent exposure to chromium, causing the mesangial cells to experience inflammation and provoking early damage to renal function ${ }^{25}$.

This research also confirmed that BMI as nutritional status associated with renal function of electroplaters. Studies conducted in Southeast Asian Population stated that increased BMI is an independent risk factor for the development of declining renal function ${ }^{26,27}$. In addition, a study of workers in Indonesia showed obesity as one of risk factors for an impaired renal function ${ }^{28}$. Complex metabolic abnormalities that can affect renal diseases are one of the consequences of obesity $^{29,30}$. An animal experimentation on a high fat diet led to obesity showed that a glomerular hyper-filtration and hyperinsulinemia in obese samples. ${ }^{31}$ Although the mechanism of excess body weight alone that lead to histologic and functional changes in kidneys is still elucidated ${ }^{30-}$ 32.

The nephrotoxicant exposure can affect the kidneys in variety of ways, determined by the exposure dose, the exposure duration and other factors that can change the susceptibility towards renal damage. Previous studies showed adverse effect of chromium exposure toward renal cell function $^{24,33}$. Chromium accumulated and stored in the kidneys will experience an oxidationreduction reaction, and an electron release happens in this process. The released electron is reactive or known as Reactive Oxygen Species (ROS). The increase of ROS in the body causes the oxidate stress, thus resulting in damage to the renal glomerulus cells ${ }^{25}$. Nevertheless, chromium exposure can cause different reactions to the kidneys and it still remains unclear ${ }^{18,34}$. This study showed no relation between urinary chromium levels and renal function based on urinary creatinine. This could be due to condition under which the urine samples were taken. The urine samples were taken on spot after 4 hours working and the workers may have urinated prior to the sampling. Chromium levels in the urine could be inadequate since after 8 hours of absorption, the kidneys can excrete as much as $60 \%$ of the $\mathrm{Cr}(\mathrm{VI})$ in the form of chromium (III) $)^{35}$. However, a study of chromium exposure in relation to renal function with different biomarkers reported that exposure to chromium did relate to renal dysfunction ${ }^{10,36}$. In addition, even though this study found no relationship between urinary chromium and urinary creatinine, the data did show amounts of urinary chromium and creatinine exceeding the threshold value, which might increase the renal impairment.

Limitation of this study were small number of samples since there were not many of electroplating workers in informal sector and how urinary samples were collected on spot 4 hours after workers starting to work may have impact on amount of urinary chromium and urinary creatinine.

\section{CONCLUSION}

There was no association between age and chromium level in the urine with renal function capacity. It may be due to on spot urinary creatinine were inadequate to indicate kidney impairment caused by $\mathrm{Cr}(\mathrm{VI})$. Working period and nutritional status had a significant association with renal function. The workers are suggested to maintain healthy lifestyle and they should wear personal protective equipment to minimize the exposure, whether a mask, rubber gloves or long sleeved clothes. The amount of time to collect 
urinary samples and adding more variables that relate to chromium exposure in metal electroplating workers can be recommendation for the next research.

\section{Acknowledgement}

We would like to express our gratitude to all of the study participants and data collectors for their dedication during data collection. And also we wish to acknowledge the help provided by Priska Ruth Dantjie, S.K.M., M.Kes for writing assistance and technical editing. In addition, this article is attributed to Dr.Praba Ginandjar, SKM, M.Biomed, may your soul rest in peace.

\section{Conflict of interest}

The authors declare no potential conflict of interest.

\section{REFERENCES}

1. Gambelunghe, A., , R. Piccinini $R, M$. Ambrogi , M. Villarini , M. Moretti , C. Marchetti, G. Abbritti GM. Primary DNA Damage in Chrome-Plating Workers. Toxicology. 2003;188:187-95.

2. Caglieri, Andrea, Matteo G., Olga A., Roberta A., Maria V., Massimo C., Pietro A. AM. The Effect of Inhaled Chromium on Different Exhaled Breath Condensate Biomarkers among Chrome-Plating Workers. Environmental Health Perspective. 2006;114(4):542.

3. Pan C, Jeng HA, Lai C. Biomarkers of Oxidative Stress in Electroplating Workers Exposed to Hexavalent Chromium. J Expo Sci Environ Epidemiol. 2018;28(1):76-83.

4. Wahyuni I, Setyaningsih Y, Ekawati. Analysis of Work Capacity and Chromium Exposure on Lung Function Capacity in Metal Coating Worker. E3S Web of Conferences. 2019;125(2019):9-11.

5. Toxicological Profile for Chromium. Agency for Toxic Substances and Disease Registry (ATSDR). 2020.

6. O'Brien T, Ceryak S, Patierno S. Complexities of chromium carcinogenesis: role of cellular response, repair and recovery mechanisms. Mutat Res. 2003;533(1-2).

7. Nordberg J AE. Reactive oxygen species, antioxidants, and the mammalian thioredoxin system. Free Radic Biol Med. 2001;31(11).

8. Zhang $X H$, Zhang $X$, Wang $X C$, Jin LF, Yang $Z P$, Jiang $C X$, et al. Chronic occupational exposure to hexavalent chromium causes DNA damage in electroplating workers. BMC
Public Health. 2011;11(224).

9. CS L, Kuo H, Lai J et al. Urinary N-acetylbeta-glucosaminidase as an indicator of renal dysfunction in electroplating workers. Int Arch Occup Environ Health. 1998;71(5):348-52.

10. Sudarsana, E., Setiani, O. S. Hubungan Riwayat Pajanan Kromium dengan Gangguan Fungsi Ginjal pada Pekerja Pelapisan Logam di Kabupaten Tegal. Jurnal Kesehatan Lingkungan Indonesia. 2013;12(1):34-41.

11. Fahrul I, Budi H. Chromium Exposure and Kidney Damage Risk among Electroplating Workers. BKM Journal of Community Medicine and Public Health. 2016;32(8).

12. Chad Haldeman-Englert M, RN LC, Raymond Turley Jr P-C. Creatinine (Urine). University of Rochester Medical Center Rochester. 2021.

www.urmc.rochester.edu/encyclopedia/c ontent . aspx? contenttypeid=167\&contentid =creatinine_urine (accessed 18 Jan 2021)

13. Hosten AO. BUN and Creatinine. In: Walker HK, Hall WD HJ, editor. Clinical Methods: The History, Physical, and Laboratory Examinations. 3rd edition. Boston: Butterworths; 1990. p. 874-878.

14. Gounden V, Bhatt H, Jialal I. Renal Function Tests. StatPearls Publishing LLC; 2020.

15. Sudigdo Sastroasmoro SI. Dasar-dasar Metodologi Penelitian Klinis. Jakarta: Binarupa Aksara; 2011.

16. Beaty RD, Kerber JD. Concepts , Instrumentation and Techniques in Atomic Absorption Spectrophotometry. Second. Norwalk, USA: The Perkin-Elmer Corporation; 1993.

17. ACGIH. TLVs and BEls. In: OH: American Conference of Governmental Industrial Hygienist, Publication No0111. Cincinnati; 2011.

18. Tsai TL, Kuo CC, Pan WH, Chung YT, Chen $\mathrm{CY}, \mathrm{Wu} \mathrm{TN}$, et al. The Decline in Kidney Function with Chromium Exposure is Exacerbated with Co-Exposure to Lead and Cadmium. Kidney International. 2017;92(3):710-20.

19. Decharat S. Chromium Exposure and Hygienic Behaviors in Printing Workers in Southern Thailand. J Toxicol. 2015;2015: 607435.

20. Antelmi A, P L, Drago I, Et A. Significance 
and Limitation of Creatinine Adjustment for Urinary Chromium and Arsenic in Biological Monitoring of Occupational Exposure to These Metallic Elements. G Ital Med Lav Ergon. 2007; 29(3 Suppl):P288-91

21. Musso CG, Oreopoulos G. Aging and Physiological Changes of the Kidneys Including Changes in Glomerular. Nephron Physiology. 2011;119(Suppl 1):P1-5.

22. Effendi I, H M. Pemeriksaan Penunjang pada Penyakit Ginjal. In: Buku Ajar Ilmu Penyakit Dalam. Jakarta: FK UI; 2006.

23. Ambreen. Genotoxicity and Oxidative Stress in Chromium-Exposed Tannery Workers in North India. Toxicol Ind Health. 2012;30(5):405-14.

24. Setyaningsih $\mathrm{Y}$, Astuti I, Husodo $\mathrm{AH}$. Determinants Levels of Urinary 8Hydroxydeoxyguanosine among Chromium Electroplating Workers. International Journal of Public Health Science (IJPHS). 2016;5(4):422.

25. Lash LH. Nephrotoxicity: Toxic Responses of The Kidney. In: Environmental and Industrial Applications. Third Edit. New Jersey: Wiley; 2015.

26. Ramirez SPAZB, Mcclellan W, Port FK, Hsu SI. Risk Factors for Proteinuria in a Large, Multiracial, Southeast Asian Population. J Am Soc Nephrol. 2002;13(7):1907-17.

27. Domrongkitchaiporn S, Sritara P, Kitiyakara C. Risk Factors for Development of Decreased Kidney Function in a Southeast Asian Population: A 12-Year Cohort Study. J Am Soc Nephrol. 2005;16(3):791-9.

28. Liem J, Mansyur M. 1636c Mining Workers, Obesity, Kidney Disease History and Hypertension Increased Risk Impaired Kidney Function among Indonesia Workers. Occupational and Environmental Medicine 2018;75:A244-A245.

29. De Boer, IH, Et al. Obesity and Charge in Estimated GFR among Older Adults. Am J Kidney Dis. 2009;54(6):1043-51.

30. Kovesdy CP, Furth SL, Zoccali C. Obesity and Kidney Disease: Hidden Consequences of the Epidemic. J Nephrol. 2017;30(1):110.

31. Henegar JR, Bigler SA, Henegar LK, Tyagi SC, Hall JE. Functional and Structural Changes in the Kidney in the Early Stages of Obesity. J Am Soc Nephrol. 2001;12(6):1211-7.
32. Garland JS. Elevated Body Mass Index as A Risk Factor for Chronic Kidney Disease : Current Perspectives. Diabetes Metab Syndr Obes. 2014;29(7):347-55.

33. Wu Y-H, Et al. Hexavalent Chromium Intoxication Induces Intrinsic and Extrinsic Apoptosis in Human Renal Cells. Mol Med Rep.2020;21(2):851-857.

34. Kulathunga MRDL, Ayanka Wijayawardena MA, Naidu R, Wijeratne AW. Chronic kidney disease of unknown aetiology in Sri Lanka and the exposure to environmental chemicals: a review of literature. Environmental Geochemistry and Health. 2019;41(5):2329-38.

35. Agency for Toxic Substances and Disease Registry (ATSDR). Case Studies in Environmental Medicine (CSEM); “Chromium Toxicity." USA: US Department of Health and Human Services. 2008;

36. Wang $\mathrm{T}$, Jia $\mathrm{G}$, Zhang J, Ma Y, Feng W, Liu $L$, et al. Renal Impairment Caused by Chronic Occupational Chromate Exposure. Int Arch Occup Environ Health. 2011;84(4):393-401. 